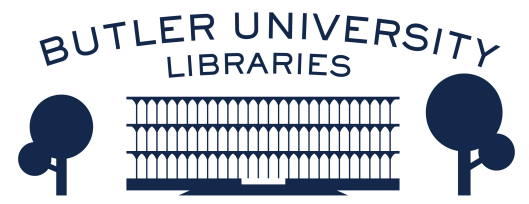

Journal of Hindu-Christian Studies

\title{
Aesthetics in Hindu-Christian Studies: A Theological Framework
}

Michelle Voss Roberts

Wake Forest University

Follow this and additional works at: https://digitalcommons.butler.edu/jhcs

\section{Recommended Citation}

Roberts, Michelle Voss (2015) "Aesthetics in Hindu-Christian Studies: A Theological Framework," Journal of Hindu-Christian Studies: Vol. 28, Article 3.

Available at: https://doi.org/10.7825/2164-6279.1602

The Journal of Hindu-Christian Studies is a publication of the Society for Hindu-Christian Studies. The digital version is made available by Digital Commons @ Butler University. For questions about the Journal or the Society, please contact cbauman@butler.edu. For more information about Digital Commons @ Butler University, please contact digitalscholarship@butler.edu. 


\section{Aesthetics in Hindu-Christian Studies: A Theological Framework*}

\section{Michelle Voss Roberts Wake Forest University School of Divinity}

ALMOST a decade ago, I saw something extraordinary at an academic conference. The presenter, Katherine Zubko, who is also the respondent for this group of essays, stepped from behind her podium and demonstrated a series of dance postures to illustrate how Christian dancers have quite literally incorporated a mantra from Hindu scripture into their own devotion. ${ }^{1}$ Something similar happened again, at an annual meeting of the American Academy of Religion, only this time the dancer was on a stage in full performance apparel for a recital. The performer, Francis Barboza, has spent his career innovating Christian-themed dance numbers in the classical Indian dance form Bharata Natyam. ${ }^{2}$ As Zubko's book, Dancing Bodies of Devotion, brilliantly illustrates, this dance form has become an important site for interreligious encounter. ${ }^{3}$ Such performances not only illustrate the dialogue between religions; they also embody it. And in making this dialogue palpable to an audience, they absorb receptive audience members into the site of the exchange.

This dance form has its roots in an ancient theory that attempts to account for the intensity and import of aesthetic experience. The Indian theory of rasa, or aesthetic "taste," begins with art's ability to transport audience members so that they taste the essence of particular emotional states, but theologians have been quick to pick it up as an analogy for religious experience. Rasāsvada is akin to brahmāsvada-in other words, emotional states produced in art can be tastes of the divine. ${ }^{4}$ Emotions become rasas when just the right physical and emotional factors combine to allow spectators to savor them in their pure form. Bharata's Nātya Śāstra originally enumerates eight aesthetic sentiments shared by all people: love, fury, compassion, disgust,

Michelle Voss Roberts, Associate Dean of Academic Affairs and Associate Professor of Theology at Wake Forest University School of Divinity, teaches in the fields of systematic, comparative, and liberation theologies. She is the author of two books and over a dozen peer-reviewed articles. Her first book, Dualities: A Theology of Difference (Westminster John Knox, 2010), received the award for the Best Book in Hindu-Christian Studies (2008-2011). In her recent book, Tastes of the Divine: Hindu and Christian Theologies of Emotion (Fordham University Press, 2014), she explores the role of the emotions in religious experience through the lens of Indian aesthetic theories. Dr. Voss Roberts currently serves as Vice President for the Society for Hindu-Christian Studies and is past co-chair of the Comparative Theology Group of the American Academy of Religion. 
terror, courage, humor, and wonder; but a later interpolation adds śānta, the peaceful sentiment. The great tenth-century literary critic and philosopher Abhinavagupta both defends śänta as the ninth rasa and designates it as the basis of a theology of religious experience. Later Gauḍiya Vaișnava theologians, particularly Rūpa Gosvāmin, further develop rasa theory by shifting the emotional center from peace to devotional love (bhakti rasa).

Building on these earlier uses of rasa theory, I submit that Indian aesthetic theory also offers a general framework for approaching Hindu-Christian studies via religious experience. Appeals to experience can be theoretically fraught because religious experience is rarely pure and unmediated. Aesthetic theory offers a way to talk about experience because it illuminates the relationship of the physical and particular aspects of religious experience to its transcendent dimensions. For a theological analysis of devotional love and other aesthetic emotions within a Hindu-Christian studies framework, my book, Tastes of the Divine: Hindu and Christian Theologies of Emotion, may be of interest to the reader. What I hope to accomplish in this paper, through a look at Abhinavagupta and the Indian Christian artist Jyoti Sahi, is to make the case that an aesthetic approach to dialogue is theologically defensible in both traditions.

\section{Abhinavagupta}

We begin with Abhinavagupta's theological application of rasa theory. He elevates the peaceful sentiment (śānta rasa) to the preeminent rasa because of its similarity to transcendent (alaukika) religious experience.
Śanta is the religious emotion par excellence in India's contemplative traditions, and, as such, it has several shades of meaning. The literary theorist Ānandavardhana uses the word sānta in the sense of "an intense experience . . . of detachment that comes from reading or witnessing a work of art depicting ruin, impermanence, the transitory character of worldly existence, and the futility of ambition." ${ }^{5}$ This momentary disillusionment with the world is conducive to liberation (moksa), especially as sought by those who renounce worldly life. Abhinavagupta expands the meaning of sañnta to include a characteristic of aesthetic experience more generally: In the unobstructed experience of rasa, one tastes the tranquil bliss of the pure self. As Abhinavagupta combines the religious and aesthetic senses of the term,

[t]he peaceful rasa may be characterized as the full development into aesthetic enjoyment of a certain type of happiness (sukha) occurring as a basic emotional state. This happiness consists in the dying off, that is, the complete cessation, of desires, that is, yearnings for objects of sense, and may be called an indifference to worldly things (nirveda). ${ }^{6}$

The culmination of aesthetic experience approximates the peaceful repose of the self in brahman, which grants the momentary cessation of conscious thought and the transcendence of subject-object duality.

Rasa's nature as alaukika-non-worldly, extraordinary, or transcendent-provides one important link to the theological import of śänta. Abhinavagupta writes, "This aesthetic relish, whose soul is supernormal (alaukika) 
wonder and whose breath is the tasting of the excitants ... [of rasa], found in poetry, should not be vitiated by identification with memory, inference, and the like." This statement sets aesthetic experience apart from quotidian life. As Abhinavagupta explains, rasa does not work like ordinary processes of feeling and thinking. It is sui generis. In contrast to ordinary emotions (sthāyibhāvas), which are produced directly, as in the joy that arises when someone receives happy news, rasa can only be produced indirectly, through suggestion. ${ }^{8}$ Aesthetic emotion is also distinct because even emotions ordinarily experienced as painful, such as terror, fury, disgust, and pathos, can be experienced as bliss through art. Furthermore, in ordinary life, emotions are related to individuals. We rejoice in our own happiness, sympathize with our friends, and despise our enemies. But in rasa, the spectator experiences sentiment neither as her own nor as related to specific people. Rasa is alaukika because it is idealized, depersonalized, or universalized (sādhāranīkrta). ${ }^{9}$ This feature of generalization names a space of affective-cum-religious experience common to all human beings.

Abhinavagupta elaborates the analogy between aesthetic relishing (rasāsvāda) and the taste of the divine (brahmāsvāda) by holding together the generalization of human emotion in rasa with the claim that it is alaukika, not of this world.

With a mind that lacks any possibility of obstruction from another sense-organ (i.e. that is completely concentrated), they enjoy (literature) because they are completely absorbed in the thrill of imaginative delight that is devoid of any thought of 'I' or 'You.' This imaginative delight is really not different from the inner experience (carvan̄a $)$ of one's own consciousness which is extremely beautiful because it is pervaded (anuvedha) by a great variety of latent impressions (propensities) of experienced happiness, sorrow, etc. ${ }^{10}$

In the theatre, as in deep meditation, one becomes completely engrossed. One forgets oneself and loses track of space and time. An extraordinary sense of wonder or mystic delight overtakes the mind of the spectator.

The same sorts of obstacles impede both aesthetic and religious experience: If a person is too immersed in his own condition, distracted by his own bodily sensations or desires, or unable to identify with the states of consciousness of others, he can fully enter neither meditation nor the realm of drama. As V. M. Kulkarni characterizes the ideal state of absorption,

Being altogether divorced from reference to personal interests, one's own or those of others, aesthetic experience is free from all the limitations of ordinary pleasure, arising out of narrow attachment, such as envy, desire or aversion; and the sahrdaya [sensitive audience member] becomes almost unconscious of his private self. He rises above the duality of pain and pleasure, love and hatred, and enjoys through disinterested contemplation absolutely pure joy or delight. ${ }^{11}$

The spectator of a work of art thus arrives at the same blissful goal as the contemplative, but by different means. Abhinavagupta concludes, "Because this [śānta] yields the highest aim of 
humanity, with the fruit of mokssa, it is preeminent among all the rasas." 12

Abhinavagupta's appeal to rasa theory thus draws upon the commonality of certain basic human affective experiences; and by drawing the link to religious experience-particularly that of peaceful transcendence-he lays down theological conditions within which Hindus and Christians may, and indeed have, found areas of resonance and dialogue.

\section{Jyoti Sahi}

Contemporary artists and philosophers contest the centrality of the peaceful sentiment because of its neglect of the sensory and material aspects of rasa. Rekha Jhanji argues that art is not essentially a spiritual activity but a sensuous experience that resides in materiality and physical form. Because Abhinavagupta approaches art from the perspective of the spectator rather than the artist, he easily slides into discussing the ideal form created in the spectator's mind rather than attending to the artist's creative manipulation of physical materials. For Jhanji, the transcendence of art experience belongs within the mundane ends of human life. Art is created and enjoyed primarily for the pleasure of the senses. Its purpose lies in the realm of kāma rather than mokșa. ${ }^{13}$ Her position does not exclude desireless contemplation from art experience, but for her this is secondary.

A similar debate takes place within Christian theology. Some theologians have observed the power of art to evoke the divine, as when Paul Tillich's "ecstatic feeling of revelatory character" in the presence of a Botticelli painting struck him as being intimately related "to the ground and the power of being." ${ }^{14}$ Others such as Hans Urs von
Balthasar caution against an aestheticizing theology that would "[betray] and [sell] out theological substance to the current viewpoints of an inner-worldly theory of beauty." ${ }^{15}$ Indian Christian theologian and artist Jyoti Sahi wrestles vigorously with this tension.

For Sahi, art is a contemplative practice or yoga. As an artist, his interest lies not only in being transported by another's performance, but also in the creation of art as a spiritual practice: "Every form of art is a yogic Sadhana, or spiritual search." ${ }^{16}$ At the Christian ashram of Fr. Bede Griffiths, the young Sahi gained a deep appreciation for Hindu and Christian spiritual practices. As an artist, he continues to be drawn to visual means of meditation such as icons and mandalas, which offer a "yoga of the heart" that disciplines a new way of seeing that goes beyond all images. ${ }^{17}$

Like Abhinavagupta, Sahi describes the transcendent experience of meditation in terms of śānta or peace, calling mandalas a potent "symbol of peace and integration." ${ }^{18}$ Prominent among his works that invite calm contemplation is the Saccidananda Chapel, which he designed for the National Biblical, Catechetical, and Liturgical Centre (NBCLC) in Bangalore. Its ascending central pillar, spatial invitations to meditation, and contemplative symbols from India's religious traditions envelop the worshiper in the peaceful sentiment. ${ }^{19}$ Even so, he acknowledges a dialectic, embedded in architectural forms, between inward and outward impulses. The Hindu temple moves inward, toward the dark womb (garbha grha) where the image of the deity resides, but Gothic Christian cathedrals articulate principles of height and light. The movement in Christianity has generally been outward: one is born from the waters, Christ is 
resurrected from the grave, and the apostles go out into the world. ${ }^{20}$ Sahi reflects that peace as a religious and aesthetic goal cannot mean an inner-worldly, aestheticizing peace alone. In the Bible, "peace in its fullness [is] when God blesses the righteous ..., protects the orphans and the poor, when all of them-the whole people" enjoy the land. ${ }^{21}$

Recall that one of the things that sets art experience apart is that it abstracts from the viewers' personal emotions so they can contemplate a particular sentiment in a shared or generalized (sādhāranikrta) way. In a variation on this principle, Sahi's art roots contemplation in experiences that are common to all, regardless of religion or casteexperiences of the elements, the earth, and the body. "Water symbolism [for example] extends beyond any religion as such, because it arises out of . . . everyday experience." ${ }^{22} \mathrm{He}$ writes of a "cosmic covenant," whereby Christians can use "natural symbols while investing them with a new meaning ... stressing the new dimension which Christianity has discovered in these ageold signs." 23

In his view of art as contemplation, Sahi is unwilling to strike an easy dichotomy between religious ends (mokșa) and the world of the senses (kāma); and despite his conviction that art culminates in śänta, he cannot ignore the suffering of Christ and the world around him. He brings a theological concern for the embodied human condition, in which both mundane and tragic events thwart the blissful repose of santra. ${ }^{24}$ With the cross, an instrument of torture and cruel death, as the central Christian symbol, art must be a discipline not only of generalized contemplation of the divine but of seeing the human condition in all its particularity.
Sahi concludes his artistic autobiography, Stepping Stones, with a reflection on the centrality of santa in this work, and in this passage we hear śānta in a new key.

I tried to express [humanity's] longing to live in peace and harmony with creation. Ultimately I feel that Christian art aspires to a new heaven and a new earth. The theme of Peace is a central theme of Christoriented art-not just a passive peace, but a creative dynamic peace, which hopes for the restoration of all things in Jesus, in whose body, which is the real and spiritual Church, all creation is bound together. ${ }^{25}$

For Sahi, then, peace is the quintessential religious longing, but it is not solely an alaukika, otherworldly affair. The equilibrium of peace cannot come at the expense of relations with material creation and other people. A HinduChristian dialogue that emerges out of such attentiveness will seek peace in the matter(s) of this world.

\section{Conclusion}

Aesthetics offers a sensory, experiential starting point for interreligious dialogue. Rasa theory observes that the physical indicators of basic emotional states are fairly stable across cultures, and these provide a basis for experiential understanding across cultural boundaries. Abhinavagupta extends this theory to posit that the experience of emotion in art parallels a generalized state of consciousness found in contemplation of brahman. Although this emphasis on common human experiences would seem to elide differences, the aesthetic analogy also teaches that when confronted with difference, one can learn other styles of 
feeling and expression. The truly cultured connoisseur (sahrdaya) is not born but made. So too, in interreligious understanding, interlocutors might identify a common religious experience as a starting point, but they may need to move forward as if learning to appreciate a new form of art.

Hindus and Christians would defend this approach in different ways. The contemporary critique and retrieval of the material element in aesthetic experience might prompt Hindus to revisit Abhinavagupta's philosophical framework. In the twentieth century, Ananda Coomaraswamy interpreted Abhinavagupta's emphasis on the peaceful sentiment in terms of Advaita Vedānta by identifying aesthetic experience with the nondual experience of brahman. ${ }^{26}$ For a proponent of a Kashmir Śaiva worldview like Abhinavagupta, however, the experience of the Absolute is never static, and awareness of union is only one moment within the dynamic self-consciousness of Siva that becomes manifest in the world of experience. ${ }^{27}$ Abhinavagupta's tantric practices conditioned him to view the world in many shades of unity and diversity. For him, thinking, breathing, enjoying a good meal, sexual ecstasy, and absorption in a work of art all testify to the selfdifferentiation of consciousness. Abhinavagupta thus does not want art simply to launch the spectator into undifferentiated union. Rather, the taste of the divine that one receives through the transporting nature of art is a taste that remains on the palate, as it were, to condition ordinary experiences of duality. Accordingly, an aesthetic disposition for dialogue would not negate particularities but attend to the subtle unfolding of commonality and difference.
Sahi's Vatican II Catholicism predisposes him toward a sanguine sense of the revelatory capacity of nature and religious experience. For him, the arts not only mediate God's gifts of nature; they also mediate grace sacramentally. He writes of church architecture that it "serves the process of sacramentalizing the body. The church building is even understood as the body of Christ. The built form helps the worshipper to discover a new dimension of being present in the body and ultimately finding the Lord enshrined within the "cave of the heart." ${ }^{28}$ As he radicalizes the notion of sacrament, he also radicalizes the incarnation, writing that "God is incarnated not only in the person of the historical Jesus but through the built forms where the divine presence continues to inspire devotion, leading individual worshippers to an experience of the continuing intervention of the divine within human cultures." ${ }^{29}$ Thus, even as he retains the priority of the peaceful sentiment, he explicitly resists an aestheticizing approach to art and theology by theorizing the sensory aspects that evoke it. For him, dialogue emerges out of an incarnational, sacramental appreciation of the divine as revealed in particular times, places, bodies, and material forms.

Along similar lines, contemporary Bharata Natyam modifies rasa theory in significant ways that impact the use of the dance form in dialogue. Because the dialogue takes place through dance, rasa's theological use has arced back to its origins in Indian dance-drama. Here, the religious experience is inextricable from the particular dancing bodies, performed stories, and audience members present at any given performance. But dance returns with a twist. Zubko explains that "When rasa theories became re-introduced and positioned as a 
privileged part of twentieth-century Bharata Natyam practice," rasa was "re-personalized." Instead of the generalized or depersonalized aesthetic "taste" sought by Abhinavagupta and other literary theorists, performers and audiences now experience Bharata Natyam as a "conduit for devotion within and through an aesthetic form." ${ }^{30}$ When performers dance a scene from the life of Krishna or Mary Magdalene, they do so to enhance their own feelings of devotion (bhakti) and those of the audience.

\section{Notes}

*Portions of this paper are drawn from Michelle Voss Roberts, Tastes of the Divine: Hindu and Christian Theologies of Emotion (New York: Fordham University Press, 2014), with permission of the publisher.

${ }^{1}$ Katherine C. Zubko, 'Embodying Bhakti Rasa in Bharata Natyam: An Indian-Christian Interpretation of Gayatri Mantra through Dance,' Journal of Hindu-Christian Studies 19 (2006).

${ }^{2}$ See, for example, Francis Barboza, Christianity in Indian Dance Forms (Delhi: Sri Satguru, 1990).

${ }^{3}$ Katherine C. Zubko, Dancing Bodies of Devotion: Fluid Gestures in Bharata Natyam (Lanham: Lexington Books, 2014).

4 Abhinavagupta discusses this analogy, originally attributed to Bhațtanāyaka, in Locana 2.4. Daniel H. H. Ingalls, Jeffrey Moussaieff Masson, and M. V. Patwardhan, The Dhvanyāloka of Ānandavardhana with the Locana of Abhinavagupta (Cambridge, MA: Harvard University Press, 1990), 226.

${ }^{5}$ Edwin Gerow and Ashok Aklujkar, "On Śānta Rasa in Sanskrit Poetics," Journal of the American Oriental Society 92.1 (1972): 83.
These examples demonstrate that an aesthetic framework for Hindu-Christian studies makes room for diverse experiences within dialogue. Not only peace and love, but also compassion, prophetic fury, and other common emotions can become the basis for understanding and solidarity. ${ }^{31}$ In each case, an aesthetic disposition toward dialogue can attend to the relationship between transcendent dimensions of religious experience and material experiences of gesture, sensory stimuli, and art.

${ }^{6}$ Locana 3.26a, trans. Ingalls, Masson, and Patwardhan, in The Dhvanyāloka of Anandavardhana with the Locana of Abhinavagupta, 521.

${ }^{7}$ Abhinavagupta, Locana 1.18, my translation. Cf. Ingalls et al., The Dhvanyāloka of Anandavardhana with the Locana of Abhinavagupta, 191.

${ }^{8}$ Abhinavagupta, Locana 1.4a. Cf. V. M. Kulkarni, Outline of Abhinavagupta's Aesthetics (Abmedabad: Saraswati Pustak Bhandar, 1998), 53-57.

${ }^{9} \mathrm{R}$. Gnoli, The Aesthetic Experience According to Abhinavagupta (Varanasi: Chowkhamba Sanskrit Series, 1985), xxii.n1; xli.

10 Abhinavagupta, Abhinavabhāratī VI.33, in Jeffrey Moussaieff Masson and M. V. Patwardhan, Aesthetic Rapture: The Rasādhyāya of the Nātyaśāstra, vol. II (Poona: Deccan College Postgraduate and Research Institute, 1970), 69n388.

${ }^{11}$ Kulkarni, Outline of Abhinavagupta's Aesthetics, 64-65.

${ }^{12}$ Locana 3.26b, my translation. Cf. Ingalls et al., The Dhvanyāloka of Ānandavardhana with the Locana of Abhinavagupta, 525. 
${ }^{13}$ Rekha Jhanji, The Sensuous in Art: Reflections on Indian Aesthetics (Shimla: Indian Institute of Advanced Study, 1989), 66.

${ }^{14}$ Paul Tillich, On Art and Architecture, ed. John Dillenberger and Jane Dillenberger, trans. Robert P. Scharlemann (New York: Crossroad, 1989), 12.

${ }^{15}$ Hans Urs von Balthasar, The Glory of the Lord: A Theological Aesthetics, Volume I: Seeing the Form, ed. Joseph Fessio, S.J., and John Riches, trans. Erasmo Leiva-Merikakis (San Francisco: Ignatius Press, 1982), 38.

${ }^{16}$ Sahi is citing Ananda Coomaraswamy. Jyoti Sahi, "The Yoga of Art," Jyoti Art Ashram (blog), July 22, 2007, http://jyotiartashram.blogspot.com/2007/07/y oga-of-art-relation-of-art-to-yoga-has.html. ${ }^{17}$ "The Yoga of the Heart in Relation to a Vision of Reality," Jyoti Art Ashram (blog), July 20, 2007, http://jyotiartashram.blogspot.com/2007/07/y oga-of-heart-in-relation-to-vision-of.html. ${ }^{18}$ Jyoti Sahi, Stepping Stones: Reflections on the Theology of Indian Christian Culture (Bangalore: Asian Trading Corporation, 1986), 57. Several of his Christian mandalas can be found at Jyoti Sahi, "Mandala of the Kingdom of Heaven." Jyoti Art Ashram (blog). October 2, 2007, http://jyotiartashram.blogspot.com/ 2007 / 10/mandala-of-kingdom-of-heaven.html.

${ }^{19}$ National Biblical Catechetical and Liturgical Center, NBCLC Campus: Milieu of God Experience, An Artistic Synthesis of Spirituality (Bangalore: NBCLC, 2005).

${ }^{20}$ See Sahi, Stepping Stones, 59-60; and Jyoti Sahi, Holy Ground: A New Approach to the Mission of the Church in India (Auckland: Pace Publishing, 1998), chapter 7.
${ }^{21}$ Martin Kämpchen and Jyoti Sahi, The Holy Waters: Indian Psalm-Meditations (Bangalore: Asian Trading Corporation, 1984), 117.

${ }^{22}$ Sahi, Stepping Stones, 168. Tribal and Dalit theologies inspire much of Sahi's thought on ecology. See, for example, Jyoti Sahi, "Dalit and Tribal Theologies," Jyoti Art Ashram (blog), September 29, 2009, http://jyotiartashram.blogspot.com/2009_09_0 1_archive.html. ${ }^{22}$

${ }^{23}$ Sahi, Stepping Stones, 166.

${ }^{24}$ Cf. Sahi, Stepping Stones, 60, 141.

${ }^{25}$ Sahi, Stepping Stones, 169.

${ }^{26}$ Ananda K. Coomaraswamy, The Dance of Siva: Essays on Indian Art and Culture (New York: Dover Publications, 1985), 35-36.

27 Jaideva Singh, "Exposition," in Abhinavagupta, Parā-trīsikā-Vivaraṇa: The Secret of Tantric Mysticism, ed. Bettina Bäumer, trans. with notes by Jaideva Singh, corrected by Swami Lakshmanjee (Delhi: Motilal Banarsidass, 1988), 52.

${ }^{28}$ Sahi, Stepping Stones, 16.

${ }^{29}$ Sahi, Holy Ground, 79. Cf. Stepping Stones, 16.

${ }^{30}$ Zubko, Dancing Bodies of Devotion, 74.

${ }^{31}$ Martha Nussbaum's thought on the ethics and rationality of emotions is helpful for more extended reflection on these subjects. See, for example, Martha C. Nussbaum, Upheavals of Thought: The Intelligence of the Emotions, (Cambridge: Cambridge University Press, 2001); and Martha C. Nussbaum, Political Emotions: Why Love Matters for Justice (Cambridge, MA: Belknap Press, 2013). 